\title{
Spirit Talk within the African Epistemological Framework
}

\author{
Taylor D. Duckett \\ ORCID iD: https://orcid.org/0000-0003-3862-6511
}

\section{Abstract}

The purpose of this essay is to present preliminary research regarding the concept of Spirit Talk as it pertains to the goals of the Sakhu. The paper rests upon the premise that the essence of all beings is Spirit. As such, there is a level of spiritual communication (Spirit Talk) that can bypass colonized linguistic systems to aid in one's recognition of themselves and others. Within this article, the relationship of the African American Christian tradition of praying in tongues was investigated in relation to the African understanding and invocation of Spirit within indigenous spiritual systems.

Spiritual frameworks, taken from the BaKongo, Dogon, Akan, and Yoruba, were used to provide context for the notion of Spirit as the primary mode of being. Furthermore, both testimony and scientific research were cited to highlight the uses of Spirit Talk as well as to explain what is happening on a physiological level when an individual is engaged in Spirit Talk. The article closes with the argument that Spirit is both knowing and knowable, absent of memetic infections and epistemological distortions.

Keywords: Spirit, Sakhu, memetic infection, epistemology, spirituality, religion, Ifá, Vodun, Christianity 


\section{Inkulumo Enomoya Phakathi Kohlaka Lwezindlela Zokwazi Zase-Afrika}

\section{Taylor D. Duckett \\ ORCID iD: https://orcid.org/0000-0003-3862-6511}

\section{Iqoqa}

Inhloso yaleli phepha ukuveza ucwaningo lokwandulela mayelana neNkulumo enoMoya njengoba inokuhlobana nezinjongo zeSakhu. Iphepha lincike ekutheni umsuka wako konke okuphilayo uMoya. Kanjalo-ke, kukhona izinga lokuxhumana ngomoya (Inkulumo enoMoya) engachezuka ezindleleni zokusetshenziswa kolimi zobukoloni ukwelekelela ukuzazi komuntu kanye nabanye abantu. Kuleli phepha, ubudlelwane benqubo yamaKhrestu babantu baseMelika abadabuka e-Afrika yokuthandaza ngezilimi buphenyiwe ngokuhlobanisa nokuqonda kwase-Afrika kanye nesicelo soMoya phakathi kwezinqubo zomoya zendabuko.

Izinhlaka zomoya, ezithathwe kuBaKongo, abaDogon, aba-Akan, kanye naBaYoruba, kusetshenzisiwe ukuveza isimo somqondo soMoya njengendlela yokuqala yokuphila. Okunye futhi, kokubili ubufakazi kanye nocwaningo lwesayensi kusetshenzisiwe ukuveza ngokugqamile ukusetshenziswa kweNkulumo enoMoya kanye nokuchaza ukuthi kwenzekani ezingeni elisemzimbeni womuntu ngesikhathi umuntu ezibandakanye eNkulumweni enoMoya. Leli phepha liphetha ngomqakuliswano wokuthi uMoya uyikho kokubili, ukwazi kanye nokwazekayo; okungekho yimithelela ekhunjulwayo kanye nokushintshashintsha kwezindlela zokwazi okungeyikho.

Amagama asemqoka: uMoya, iSakhu, umthelela okhunjulwayo, izindlela zokwazi, ukukhonza uMdali, inkolo, i-Ifá, iVodun, inkolo yobuKhrestu 


\section{Introduction}

Within the African consciousness, Spirit can be defined as the primary unit of being and the genesis of our existence. According to African thought, "we are spirit beings housed in a physical container having a human experience' (Nobles 2018: 2). To take this thought a step further, not only are individuals spirit beings, as opposed to human beings as characterised by Western narratives, divinity is inherent. The African consciousness acknowledges the Creator and does not force a separation between the Creator and created. Instead, the relationship between the Creator and the created is one of close fellowship and regular interaction. This contradicts the Western framework as their systems operate under the premise that the Creator is distant and not able to be connected with on a deep, meaningful level.

To further the discussion of beings as Spirit, it is important to note the differences between spirituality and religion. Spirituality refers to 'The outward expression of one's understanding of their relation to the Divine, driven by the guiding of a supernatural force either internal or external to themselves' (Duckett 2018: 3). Conversely, religion is the counterfeit of spirituality. It can be defined as 'a manmade institution designed to press individuals and societies into a particular school of thought where, in many ways, the doctrine is held in higher esteem than the deity or deities supposed to serve as the focal point, creating a cycle of dependency upon which its adherents are forced to rely for wisdom, guidance, and wellbeing' (Duckett 2018: 3). Spirituality should not be confused with spiritness (Nobles 2015b). Spirituality is the expression of Spirit; spiritness is the state of being Spirit, the essence of one's being (Nobles 2015b). The introduction of religion to enslaved Africans, and those subjected to colonialism, created a fracture within the African consciousness, which allowed for the unchecked growth of harmful memetic infections (Nobles 2015a). Spirituality sets individuals and societies free as they are able to follow the divine guidance of a supernatural force. Religion, however, keeps its adherents in bondage as the relationship between the individual and the Divine has been severed or severely altered. With religious systems, one is not expected to be an active participant in obtaining growth, inner healing, peace, and other blessings. Instead, one is expected to be a faithful adherent to the rules and regulations prescribed by the religious system in place, believing everything, and questioning nothing. Religion also promises eternal life, prosperity, and things already available to those who are spiritually connected. Spirituality grounds an individual, while religion binds them. 
It is the binding and restricting nature of religion that permits unchecked growth of memetic infections. A memetic infection is defined as 'The process by which sensorial information structures symbiotically infect the mind or consciousness so as to reinforce and/or propagate the sensoria' (Nobles 2015a: 55). The main point of infection is creating a cycle of dependency instead of a sankofic relationship as was intended. Sankofa is a Ghanaian word from the Akan symbolising the need to return. Its meaning is to go back and get what was left behind or forgotten. Sankofa is a way of being that promotes a circular relationship involving Spirit, the Ancestors, the natural world, the individual, and the community. To have a sankofic relationship means to be actively engaged in remembering the past to retrieve and reclaim the epistemologies and expressions of Spirit that are needed to carry out purpose in the present. When left unresolved, memetic infections spread and become epistemological distortions which are, 'an interruption of, or interference with, original thought or ways of knowing and producing knowledge that result in marginalisation and the formation or adaptation of false identities' (Duckett 2018: 2). Within the context of spirituality, memetic infections and epistemological distortions result in the minimisation of Spirit and associated phenomena. Furthermore, religion elevates a particular Divinity, while purposefully seeking to diminish the divinity within each person. Religion teaches its adherents not to recognise that Spirit is in everyone and everything, rendering them unable to recognise themselves and others as having shared humanity.

The concept of Spirit as being is exemplified in indigenous spiritual traditions such as Ifá and Vodun. On March 3, 2019, during divination with a New Orleans based Vodun Mambo (priestess), the Mambo explained the relationship between Spirit and being as follows:

There is no rule book for working with the Lwa or the Orisa like there is in Christianity. The Lwa and Orisa are forces of energy that exist to work with us and take us into a deeper expression of Spirit, beyond the superficial of the Judeo-Christian understanding of Spirit. We are to work with Spirit and incorporate the Lwa and Orisa energy into our lives on a daily basis. We do not exist to be bound by rules and theology.

Based on this interpretation of being, it can be implied that in order for one to walk in their specific destiny, they must work with and engage Spirit on a 
Spirit-to-Spirit level that supersedes what is considered within western frameworks as 'the natural'.

\section{Spirit Talk}

In İwúre: Healing Power of Prayer, the Araba of Osogbo in Nigeria noted that prayer is what is said or communicated with the Divine All (God) wherein one speaks positive words in order to ensure the fulfilment of one's request or petition. It is a method of communication that is no respecter of spiritual systems as Spirit is able to communicate with those who are receptive regardless of where they are spiritually located. Within Ifá and Vodun, in addition to prayer, Spirit talk may manifest through the practice of divining. Within the JudeoChristian context, the practice of engaging the prophetic has a similar ontological and epistemological purpose to divination. Having been a participant in the Pentecostal denomination of Christianity for several years before leaving the Church, there has been ample exposure to the prophetic both as a recipient of messages and as a conduit through which messages were given. One such message, given by a Christian minister, ordained as a Prophet, on December 4, 2015, stated, 'There is a teaching anointing on your life, and there is a craft in your hands'. When seeking out Ifá divination, the revelation regarding destiny was reiterated on March 24, 2019, by the Íyánifá with the following statement, 'You need to capitalise on the gifts of your artistry'. On October 21, 2019, during an a different Ifá divination with a Babalawo, this same message regarding professional and creative endeavours was reiterated. These complimentary readings across spiritual systems are possible because Spirit transcends societal constructs and does not contradict itself in its desire to be known.

The nature of reality, when discussing it from the African epistemological framework, is that all have a spirit that is both knowing and knowable (Nobles 2015b). From this statement, it can be gathered that if Spirit is knowing and knowable, there must be a language that it employs as its method of communication. This language could be defined as Spirit talk. Spirit is said to vibrate in seven directions, which are: upward (beyond), inward (being - to heal), backward (beginning), rightward (belonging), leftward (becoming), downward (be), and frontward (beholding) (Fu-Kiau 2001). Spirit talk is, at its core, energy that vibrates in accordance with the direction of the spirit. Spirit talk can also be defined as a manifestation of nommo. Nommo are the ancestral spirits of the Dogon (Mali), and nommo intends to bring balance 
and harmony. Nommo invokes Spirit to create a harmonious dialogue that inspires one to forward action, thus, making it an example of Spirit talk as Spirit moves the words. This concept has been further defined as the power and intention behind the word (Ani 1992). Though nommo is related to the word, be it spoken, written, sung, or otherwise, it also transcends the word similarly to how Spirit transcends the mind.

It is appropriate to note that just like the spirit vibrates in different directions, there are different directions and levels of Spirit talk that can be employed. Spirit talk can be expressed in the following directions: humanspirit to human-spirit (ex. person to person), human-spirit to Egun (Ancestor), human-spirit to the spirit within the matter and substance of nature (ex. person speaking to the water or crystals), and human-spirit to the Creator/Divine. The four directions that Spirit talk can be employed in, if drawn out, would take on the cruciform shape that is the basis of the Yowa, a Kongo cosmogram for the continuity of life (Thompson 1983).

The horizontal line of the Yowa denotes the Kalunga (Fu-Kiau 2001), and it divides the living and ancestral realms (Thompson, 1983). The points at each end of the axes of the Yowa represent the movement of humanity through life. Moving counterclockwise from the rightmost point, the Yowa cosmogram depicts a person's movement from birth to maturity, from maturity to death, from death to Ancestor, and from Ancestor back to birth (Thompson 1983). If the four directions of Spirit talk were similarly positioned, the movement would be from human-spirit to human-spirit, to human-spirit to the Creator/ Divine, to human spirit to the natural world, to human-spirit to ancestral spirits, and then back to human-spirit to human-spirit. As stated by Fu-Kiau (2001:17), 'For an African Mûntu, the dead are not dead: they are beings living just beyond the wall waiting for their probable return to the community, to the physical world'. With this understanding of the BaKongo view of life, death, and Spirit as it pertains to the Yowa, the interconnected nature of being is possible only through the continual communication of human-spirits with the other human-spirits, natural spirits, ancestral spirits, and the Creator/ Divine.

Within the African American Christian tradition, Spirit talk can manifest as glossolalia, praying or speaking in tongues. Though some denominations accept tongues as a valid expression of a spiritual experience, others categorise it as demonic, improper, and potentially bordering on blasphemy. Some have made a spectacle of this form of Spirit talk, diminishing it to the level of idle chatter instead of the divine speech (Carruthers 1995) of which it 


\section{Taylor D. Duckett}

is a derivative. Furthermore, it can be argued that when appropriately used, Spirit talk that manifests as praying in tongues is the retention of African spirituality that has been syncretized within certain Christian frameworks, as opposed to a tradition that was birthed out of the Judeo-Christian recognition of Pentecost.

A study conducted by the University of Pennsylvania has provided scientific evidence to support Spirit talk as a spiritual exercise that does not involve the functions of the mind with regards to language and active thought. This experiment was conducted by taking brain images of five women while they were singing a worship song and then again while praying in tongues. While praying in tongues, it was noted that the frontal lobe and language processing center were not active, though the part of the mind that controls awareness was active (Carey 2006). This highlights the fact that Spirit can communicate without having to engage the mind, as it is traditionally understood, to do so. This implies that Spirit can communicate in a noncolonised manner, one that is able to bypass the memetic infections that may be present within the mind. The study went further to state that those who prayed in tongues showed no signs of mental illness and that they appeared more emotionally stable and grounded than those who did not engage in this practice (Carey 2006). This conclusion supports the premise that humanity is at its essence Spirit, and therefore when Spirit is given room to speak and acknowledge the Spirit of others, Spirit is kept in balance as it is not being grieved or quenched.

Though most Spirit talk, such as praying in tongues, is directed as being from the human-spirit to the Creator/Divine, it is possible to have Spirit talk active on a human-spirit to human-spirit (person to person) level. Some have labelled this action discernment, namely the ability to sense in the spirit that which is not readily available in natural language. Within the course, Africana Studies 705: Seminar in Africana Studies at San Francisco State University, taught by Dr. Wade Nobles, students were tasked with uncovering hidden episteme. An epistemic reflection titled, Vibratory Energy: Praying in Tongues was presented for discussion. The premise behind the research conducted was to discern the impact that engaging in Spirit talk by the water would have on the water and the student. To conduct this analysis, the student chose to invoke Spirit through the use of the Djembe and praying in tongues while in the presence of the San Pablo Bay in Pinole, California. Having been trained in a religious tradition that acknowledged Spirit talk but not the 
interpretation of it, she sought to test if the concept of a knowing and knowable Spirit was applicable to the practice of praying in tongues. While invoking Spirit, the student took an audio recording to divine an English interpretation of Spirit talk that she could apply to her own life. When presenting the research and findings, the audio clip was played to allow those in attendance to hear the changes in the water as well as the Spirit talk that manifested as praying in tongues. After listening to the audio recording, one of the attendees to the reflection remarked, 'Though I did not understand the words that you were saying, I understood you'. Upon first encounter, Spirit talk has no English or 'natural' language protocol. As highlighted by Bettina Judd in Glossolalia: Lucille Clifton's Creative Technologies of Becoming, tongues should be understood as 'a form of knowledge that refuses comprehension and is whole unto itself' (Judd 2019:147). It comes from Spirit and is therefore processed and understood by Spirit.

When tracing the African lineage of praying in tongues, it is important to note that the majority of Africans were taken from the Bantu region of Africa. Within the spiritual practices that people from this region carried with them, there would be prayers to invoke specific deities or impact the energy of the natural world in some form. During these ceremonies, a worshipper may be mounted by the deity that they sought an audience with and had performed ritual to invoke. From there, the language of their prayers would change from the known to the unknown realm of Spirit Talk. This parallels the African American description of what happens while praying in tongues, because it is often described as being overtaken by the Holy Spirit, and the person serving as the medium has their language switched from the known to the unknown as it pertains to what is considered natural language. Furthermore, there are often other spiritual elements present, particularly drums, that help set and inevitably shift the atmosphere to one conducive to receive the deity being invoked. The use of other spiritual elements within ritual and worship, further demonstrates the viability of Spirit talk as it pertains to communication between humanspirits and the spirit of the drum as well as natural/ elemental spirits.

\section{Conclusion}

There is a strong connection between the knower, the knowing, and the known, and the experiences of those who utilise Spirit talk regularly through praying in tongues or corresponding acts of worship within other spiritual systems. This 
process ties into the goal of the Sakhu, which is defined as the illumination of the human spirit (Nobles 2018). The Irt hr skh is proposed as a way of engaging in a deep, profound and penetrating search, study, understanding, and mastery of the process of illuminating the human spirit and reality (Nobles 2018). Spirit talk is a means through which to do this, because Spirit is knowing (able to communicate) and knowable (able to be understood) by the individual, as well as others. The knower is thus positioned to recover or access what was once unknown through bypassing the mind in favour of direct communication with Spirit. Spirit talk allows one to come away with new knowledge or knowing about themselves, others, or the world around them.

\section{References}

Ani, M. 1992. Let the Circle be Unbroken: The Implications of Spirituality in the Diaspora. Trenton, NJ: Red Sea Press.

Carey, B. 2006. November 07. A Neuroscientific Look at Speaking in Tongues. Available at:

https://www.nytimes.com/2006/11/07/health/07brain.html

Carruthers, J.H. 1995. MDW NTR-Divine Speech: A Historical Reflection of African Deep Thought from the Time of the Pharaohs to the Present. Trenton, NJ: Red Sea Press.

Duckett, T. 2018. Epistemological Distortions as a Means of Oppression.

Unpublished manuscript, San Francisco State University.

Fu-Kiau, K.K.B. 2001. Tying the Spiritual Knot: African Cosmology of the Bantu-Kongo. $2^{\text {nd }}$ Edition. Brooklyn, NY: Athelia Henrietta Press.

Judd, B. 2019. Glossolalia: Lucille Clifton's Creative Technologies of Becoming. In Black Bodies and Transhuman Realities. Lanham: Lexington Books.

Nobles, W.W. 2015a. The Island of Memes: Haiti's Unfinished Revolution. Baltimore, MD: Black Classic Press.

Nobles, W.W. 2015b. From Black Psychology to Sakhu Djaer: Implications for the Further Development of a Pan African Black Psychology. Journal of Black Psychology 41: 399 - 414.

https://doi.org/10.1177/0095798413478072

Nobles, W.W. 2013. Shattered Consciousness, Fractured Identity: Black Psychology and the Restoration of the African Psyche. Journal of Black Psy- 
chology 39,3: 232 - 242. https://doi.org/10.1177/0095798413478075

Nobles, W. 2018. Personal Communication, Class discussion, AFRS 705:

Seminar in Africana Studies - The Production of Africana Knowing, Contested Genealogy [PowerPoint Slides].

Thompson, R.F. 1983. Flash of the Spirit: African \& Afro American Art \& Philosophy. New York, NY: Vintage Books.

Taylor D. Duckett Department of African American and African Diaspora Studies Indiana University Bloomington tdducket@iu.edu 